\title{
PERTANGgUNGJAWABAN PENDISTRIBUSIAN \\ PEMBAYARAN ZAKAT ON LINE
}

\author{
MOH. ZAINUDIN \\ Fakultas Hukum, Universitas Wiraraja Sumenep \\ zainuddin@gmail.com
}

\begin{abstract}
ABSTRAK
Zakat juga merupakan salah satu rukun Islam dan menjadi kewajiban agama yang dibebankan atas harta kekayaan seseorang menurut aturan tertentu. Perkataan zakat disebut dalam Al Qur'an sebanyak 82 kali dan selalu dirangkaikan dengan shalat yang merupakan rukun Islam yang kedua. Zakat sendiri dalam Islam merupakan hubungan yang dapat bersifat vertikal dan horisontal. Maksud bersifat vertikal adalah zakat dimaksudkan hubungan ibadah antara manusia dengan Allah (habluminallah). Sedangkan horisontal maksudnya adalah hubungan antara manusia dengan manusia yang lain atau dengan lingkungan masyarakatnya (habluminannas). Adanya wajib zakat bagi yang mampu, diharapkan akan ada kepedulian dari kaum yang dianggap "mampu” untuk membantu para saudaranya yang masih dibawah kemiskinan sehingga akan mengurangi jumlah masyarakat yang dibawah garis kemiskinan di Indonesia.
\end{abstract}

Kata kunci: Pendistribusian Pembayaran Zakat On Line.

\section{A. PENDAHULUAN}

Kemiskinan secara sosiologis dapat diartikan sebagai keadaan seseorang yang tidak sanggup memelihara dirinya agar sesuai dengan taraf kehidupan kelompok, dan juga tidak mampu memanfaatkan tenaga mental maupun fisiknya dalam kelompok tersebut. Ukuran untuk menentukan batas kemiskinan tidaklah mudah, tetapi para fuqaha (ahli fiqih) mengemukakan sifat yang melekat pada kemiskinan, yaitu seseorang yang tidak memiliki sesuatu baik harta maupun tenaga, atau seseorang yang masih mampu berusaha memperoleh harta secara halal, tetapi hasilnya tidak mencukupi kebutuhan bagi dirinya dan keluarganya. Disisi lain, krisis ekonomi melanda Indonesia sejak tahun 1998 sampai sekarang masih berkelanjutan.
Angka kemiskinan semakin meningkat, pengangguran membengkak, kualitas pendidikan menurun, pelayanan sosial memburuk, kekurangan gizi, kerusuhan terjadi dimana-mana sehingga menimbulkan konflik sosial. Kebijakan-kebijakan pemerintah belum mampu mengatasi berbagai krisis yang terjadi sebagai akibat dari krisis ekonomi tersebut. Sampai sekarang krisis ini masih terus berlanjut, sehingga besar kemungkinan jumlah kemiskinan akan terus bertambah bila tidak ada penanganan dari berbagai pihak selain pemerintah. Agar sumber dana dapat dimanfaatkan bagi kesejahteraan masyarakat terutama untuk mengentaskan masyarakat dari kemiskinan perlu adanya sikap dari pemerintah mengingat masalah kemiskinan 
menjadi tanggung jawab Negara, salah satunya dengan zakat.

Melihat kondisi kemiskinan yang ada di Indonesia yang semakin naik, setidaknya dana zakat (beserta infaq, shadaqah, wakaf, dan sejenisnya) dengan potensinya yang demikian besar, dapat berperan membantu pemerintah dalam mengatasi berbagai problem sosial tadi. Zakat merupakan salah satu nilai instrumental dalam ekonomi Islam.

Zakat berasal dari bentukan kata zakat yang berarti "suci, baik, berkah, tumbuh, bersih dan bertambah". Menurut terminologi syariat (istilah), zakat adalah nama bagi sejumlah harta tertentu yang telah mencapai syarat tertentu yang diwajibkan oleh Allah untuk dikeluarkan dan diberikan kepada yang berhak menerimanya dengan persyaratan tertentu pula. Kaitan antara makna secara bahasa dan istilah ini berkaitan erat sekali, yaitu, bahwa setiap harta yang sudah dikeluarkan zakatnya akan menjadi suci, bersih, baik, berkah, tumbuh, dan berkembang, sebagaimana terdapat dalam Firman AllahSWT dalam Al-Qur'an surat At Taubah ayat 103 yang terjemahannya sebagai berikut: "Ambil sedekah zaka) dari hartaharta mereka, engkau membersihkan dan menyucikan mereka dengan sedekah tersebut"

Sedangkan zakat menurut Undangundang tentang Pengelolaan Zakat pada pasal 1 angka (2), pengertiannya adalah "harta yang wajib disisihkan oleh seorang muslim atau badan yang dimiliki oleh orang muslim sesuai dengan ketentuan agama untuk diberikan pada yang berhak menerimanya". Dari sini jelaslah bahwa kata zakat, dimaksudkan sebagai "penunaian", yakni hak wajib terdapat dalam harta. Zakat juga dimaksudkan sebagai bagian harta tertentu dan yang diwajibkan oleh Allah untuk diberikan pada orang-orang fakir. Zakat dinamakan sedeka karena tindakan itu akan menunjukkan kebenaran "shidq" seorang hamba dalam beribadah dan melakukan kegiatan kepada Allah swt.

Mobile-Zakat( M-Zakat) adalah salah satu terobosan penggunaan jasa komunikasi seluler dalam penghimpunan zakat yang menitik beratkan pada pengelolaan sisi muzakki, dimana lebih banyak melakukan penghimpunan dana sebanyak-banyaknya dari muzakki. Oleh karena itu, M-Zakat disebut sebagai fasilitator atau bagian dari fungsi fundraising yang di outsource kepada swasta. Konsep M-Zakat dapat dianalogikan fasilitator yang mengantarkan muzakki ke kantor amil zakat untuk menyerahkan zakatnya. Bertolak dari logika ini, M-Zakat tidak memposisikan diri sebagai amil, melainkan sebagai pelaksana syi'ar serta penyedia sarana pembayaran zakat dengan memanfaatkan teknologi komunikasi seluler.

M-Zakat sendiri adalah sebuah produk layanan SMS berkonsep lintas operator, lintas amilzakat dan lintas mustahik yang bertujuan untuk menjawab kebutuhan para pembayar zakat yang sering mengalami kendala teknis dan waktu dalam membayarkan zakatnya, dengan memberikan kemudahan membayar zakat lewat SMS telepon seluler. 
Berdasarkan ketentuan Pasal 11 Undangundang tentang Pengelolaan Zakat, zakat terdiri atas (1) zakat malatau zakat harta, dan (2) zakat fitrah. Zakat harta adalah bagian dari harta kekayaan seseorang (juga badan hukum) yang wajib dikeluarkan untuk golongan orang-orang tertentu setelah dipunyai selama jangka tiap hari raya Idul Fitri, diwajibkan atas tiap-tiap orang Islam laki-laki dan perempuan untuk membayar zakat fitrah banyaknya 3,1 liter dari makanan yang mengenyangi menurut tiap-tiap tempat (negeri). Dari Ibnu Umar, Rasulullah saw mewajibkan "Zakat Fitri sama dengan berbuka bulan Ramadhan, sebanyaknya satu sha' (3,1 liter) tamar atau gandum atas tiaptiap orang Muslim merdeka atau hamba, lakilaki atau perempuan" (H.R Bukhari dan Muslim). Objek zakat yang dijelaskan secara rinci dalam Alquran dan hadis Nabi ada lima macam, yaitu hewan ternak, hasil pertanian, barang tambang, emas, perak dan perdagangan. Sedangkan menurut Didin Hafidudhin, dalam kaitan sektor perekonomian modern objek zakat semakin meluas, yakni mencakup sektor Zakat Profesi, Zakat Perusahaaan, Zakat Surat-surat Berharga, Zakat Perdagangan Mata Uang, Zakat Hewan Ternak yang Diperdagangkan, Zakat Madu dan Produk Hewani, Zakat Investasi Properti, Zakat Asuransi Syari'ah, Zakat tanaman anggrek, ikan hias, burung walet, dan sebagainya, serta Zakat aksesoris rumah tangga modern.

\section{B. PEMBAHASAN}

Fungsi telekomunikasi tidak dapat dilepaskan dari konsep M-Zakat. Dimana dalam pelaksanaannya pembayaran zakat dilakukan melalui SMS (Short Massage Service). Berdasarkan Peraturan Direktur Jendral Pos dan Telekomunikasi Tahun 2006 tentang Penyelenggaraan Jasa Pesan Singkat (SMS) adalah jasa telekomunikasi berupa pengiriman dan atau penerimaan pesan singkat melalui jaringan telekomunikasi. Sedangakan dalam butir 13 disebutkan bahwa Penyedia konten adalah penyedia layanan program tertentu yang disebarluaskan kepada pelanggan telekomunikasi.

Asas penyelengggaraan telekomunikasi menurut Pasal 2 Undang-Undang Nomor 36 Tahun 1999 tentang Telekomunikasi diselenggarakan berdasarkan :

a. Asas manfaat berarti pembangunan telekomunikasi khususnya penyelenggaraan telekomunikasi akan lebih berdayaguna dan berhasil guna balk sebagai infrastruktur pembangunan, sarana penyelenggaraan pemerintahan, sarana pendidikan, sarana perhubungan maupun sebagai komoditas ekonomi yang dapat meningkatkan kesejahteraan masyarakat.

b. Asas adil dan merata merujuk pada penyelenggaraan telekomunikasi memberikan kesempatan perlakuan yang sama kepada semua pihak yang memenuhi 
syarat dan hasil-hasilnya dinikmati olehmasyarakat secara adil dan merata.

c. Asas kepastian hukum mempunyai pengertian bahwa pembangunan telekomunikasi, khususnya penyelenggaaraan telekomunikasi, harus didasarkan kepada peraturan perudangundangan yang menjamin kepastian hukum dan memberikan perlindungan hukum, baik bagi para investor, penyelenggara telekomunikasi, maupun kepada penggunatelekomunikasi.

d. Asas kepercayaan pada diri sendiri merujuk pada telekomunikasi dilaksanakan dengan memanfaatkan secara maksimal potensi sumberdaya nasional secara efisien serta penguasaan teknologi telekomunikasi sehingga dapat lebih meningkatkan kemandirian dan mengurangi ketergantungan sebagai suatu bangsa dalam menghadapi persaingan global.

e. Asas kemitraan memiliki makna bahwa penyelenggaraan telekomunikasi harus dapat mengembangkan iklim yang harmonis, timbal balik, dan sinergis dalam penyelenggaraan telekomunikasi.

f. Asas keamanan seperti dimaksud di atas agar dalam penyelenggaraan telekomunikasi faktor keamanan dalam perencanaan, pembangunan dan pengoperasian harus selalu diperhitungkan.

g. Asas etika dimaksudkan agar dalam penyelenggaraannya, telekomunikasi senantiasa harus dilandasi semangat profesionalisme, kejujuran, kesusilaan dan keterbukaan.

Demikian juga dalam penyelengaraan M-Zakat yang tentunya sangat cocok dengan asas-asas penyelengaraan telekomunikasi di Indonesia. Dengan mengacu pada asas-asas penyelenggaraan telekomunikasi tersebut, M-Zakat sendiri bertujuan untuk menciptakan kesempatan yang besar bagi para muzakki yang merupakan pengguna telepon seluler yang biasanya untuk berkomunikasi dalam hal ini digunakan untuk mempermudah sarana ibadah kepada Allah dan juga untuk membantu sesama umat yang termasuk dalam asnaf mustahik.

Dengan adanya penyelenggaraan MZakat ini, bukan hanya pemerintah yang diuntungkan karena membantu mengentaskan kemiskinan dan memberikan kesejahteraan terhadap kaum yang membutuhkan namun juga muzakki sendiri serta penyelenggara jasa serta operator seluler. Selain mengentaskan kemiskinan dan memberikan kesempatan yang sama terhadap semua pihak yang ingin berpartisipasi dalam MZakat khususnya dan kemajuan telekomunikasi pada umumnya, M-Zakat ini juga dilandasi semangat profesionalisme, kejujuran, kesusilaan dan keterbukaan. Contohnya adalah dalam hal keterbukaan perolehan jumlah SMS yang disampaikan secara teratur dalam websitenya. Hal ini menandakan adanya semangat 
profesionalisme yang melandasi manajemen pengelolaannya.

Dana yang terkumpul melalui SMS tersebut akan langsung masuk ke account amil, lengkap dengan pilihan mustahiknya, sesuai dengan keinginan muzakki. Proses pengumpulan dana sampai pada penyaluran dana kepada amil diawasi oleh Majelis Syariah M-Zakat, yang diaudit oleh lembaga auditor independen secara periodik dan akan diumumkan hasilnya melalui media massa. Proses tersebut menandakan profesionalisme dalam pengelolaannya $\mathrm{M}$ Zakat.

Adanya kepastian hukum berarti bahwa konsep ini tidak bertentangan dengan hukum Islam, Undang-Undang Telekomunikasi dan Undang-Undang tentang Pengelolaan Zakat memberikan jaminan kepastian dan terhadap para pengguna dalam hal ini adalah calon muzakki. Selanjutnya pada ketentuan Pasal 3 UndangUndang Nomor 36 Tahun 1999 tentang Telekomunikasi menyebutkan tujuan dalam penyelenggaraan telekomunikasi yaitu untuk mendukung kesatuan dan persatuan bangsa, meningkatkan kesejahteraan dan kemakmuran rakyat secara adil dan merata/ mendukung kehidupan ekonomi dan kegiatan pemerintahan serta meningkatkan hubungan antar bangsa.

Tujuan penyelenggaraan telekomunikasi ini dapat dicapai antara lain melalui reformasi telekomunikasi untuk meningkatkan kinerja penyelenggaraan telekomunikasi dalam rangka menghadapi globalisasi, mempersiapkan sektor telekomunikasi memasuki persaingan usaha yang sehat dan profesional dengan regulasi yang transparan, serta membuka kesempatan lebih banyak bagi pengusaha kecil dan menengah. Dalam M-Zakat sendiri, perjanjian sewa jarlngan untuk penyelenggaraan sistem ini diatur dalam Pasal 9 Undang-Undang Telekomunikasi, dimana penyelenggara jaringan yang dalam hal ini adalah operator seluler dapat menyewakan jaringannya kepada penyelenggara jasa layanan atau penyedia konten. Tarifnya sendiri diatur pada pasal 27 dan 28, Undang-undang Telekomunikasi.

Hal lain yang terkait dengan efektifitas pembinaan,dalam undang-undang ini, disebutkan bahwa dalam melakukan kegiatan pembinaan maka Pemerintah melakukan koordinasi dengan instansi terkait, penyelenggara telekomunikasi dan mengikutsertakan peran masyarakat. MZakat dalam hal ini adalah sebuah terobosan dalam telekomunikasi dan sistem zakat yang mengikutsertakan pemikiran masyarakat tentang bagaimana telekomunikasi dapat membantu pelaksanaan pengumpulan zakat yang efektif dan efisien serta tidak bertentangan dengan peraturanperaturan yang terkait. Pengawasannya selain oleh Majelis Syariah Independen yang telah ditunjuk juga oleh Badan Regulasi Telekomunikasi Indonesia. 
Sedangkan jika ditinjau dalam konsep istilah sendiri, sebenarnya penamaan M-Zakat terlalu luas. "M" dari kata Mobile yang berarti aktif, giat, gesit dan dapat berpindah-pindah. Sehingga penamaan ini telalu luas untuk konsep MZakat yang mengkhususkan dirinya terhadap SMS. Mobile sendiri dapat juga berarti segala sesuatu dalam telekomunikasi secara luas, bisa telefon, internet, ATM, kartu kredit, kartu debet dan transferrekening bank yang juga menggunakan jaringan telekomunikasi dan sifatnya juga bergerak. Seharusnya panamaan yang sesuai adalah dengan "Zakat SMS" atau "SMS Zakat", karena lebih mudah diketahui oleh masyarakat umum dan sesuai dengan konsep yang diusungnya.

Mekanisme dalam pengelolaan zakat melalui tiga tahap, yaitu penghimpunan, pengelolaan dan pendayagunaan. Setelah mengetahui bagaimana penghimpunan zakat melalui konsep Mobile-Zakat, maka selanjutnya dalam pembahasan ini penulis akan mengupas bagian efektifitas pendistribusian dan pendayagunaan zakat. Melalui pemberdayaan pengelolaan zakat yang produktif diharapkan melahirkan muzakki-muzakki baru. Para mustahik di dorong untuk menggunakan dana zakat selain untuk memenuhi kebutuhan hidupnya (konsumtif) juga berorientasi produktif, yaitu mengembangkan potensi usaha yang dimilikinya untuk berkembang.
Para amil zakat selaku pengemban amanah pengelolaan dana-dana yang terkumpul merupakan unsur yang terpenting dan tidakboleh dilupakan. Jika amil zakat baik, maka tujuh asnaf mustahik lainnya insya Allah akan menjadi baik. Itulah nilai strateginya amil zakat. Dengan kata lain, hal terpenting dari zakat adalah bagaimana mengelolanya. Dalam layanan pilihan MZakat, terdapat pilihan dimana muzakki mempunyai hak untuk memilih amil zakatnya dan tidak memilih amil zakatnya. Apabila muzakki tidak memilih siapa amil zakatnya, Majelis Syariah yang kemudian memutuskan bagaimana cara membaginya diantara para amil secara adil. Pilihan mustahik dalam M-Zakat ini adalah sebagai berikut : 1) Fakir, 2) Miskin, 3) Muallaf, 4) Raqib, 5) Gharim, 6) Fisabilillah, dan 7) Ibnusaabil.

Di dalam Al-Quran sendiri terdapat delapan golonganyang berhak untuk menerima zakat. Golongan yang disebutkan di dalam surat At Taubah ayat 60 itu antara lain : 1) Fakir, 2) Miskin, 3) Muallaf, 4) Raqib (hamba sahaya), 5) Gharim (orang yang berutang), 6) Fisabilillah (orang yang berada di jalan Allah), dan 7) Ibnusaabil (orang yang sedang dalam perjalanan).

Besarnya SMS yang sudah ditentukan yaitu Rp. 12.500,- (dua belas ribu lima ratus rupiah) tersebut murni disalurkan kepada amil zakat yang kemudian diteruskan kepada mustahik yang telah dipilih oleh muzakki. Tidak ada 
pemotongan biaya lain-lainnya, karena untuk layanan jasa M-Zakat operator telah memotong sejumlah pulsa yang berkisar antara Rp. 1.500,- sampai dengan Rp. 2.500,00 selain pemotongan besarnya zakat yang ditentukan, untuk biaya kelola $\mathrm{M}$ Zakat. Pemotongan sejumlah pulsa untuk biaya kelola layanan itu sendiri merupakan profit sharingantara penyelenggara jasa SMS dengan operator seluler.

Sedangkan untuk amilsebagai salah satu mustahik tidak akan dapat bagian dari MZakat, karena dalam M-Zakat ada pilihan "bebas" dimana muzakki menyerahkan sepenuhnya kepada amil untuk mengalokasikan dana zakat serta memilih mustahik. Amil diperbolehkan mengambil bagian $12,5 \%$ dari pilihan bebas ini. Muzakki dapat mengetahui berapa jumlah zakat yang terkumpul oleh amil zakat tertentu dan kemana saja dana zakat tersebut digunakan. Dalam hal ini, amilzakat memang diwajibkan untuk memberikan entrydata atas dana zakat yang mereka peroleh. Ini sebagai bentuk pertanggungjawaban dan transparansi. Informasi mengenai jumlah perolehan zakat SMS tidak harus melalui telepon seluler dengan fasilitas SMS, namun muzakki juga dapat memantau perkembangan dana zakat dan pendayagunaan melalui internet, dengan alamat www.m-zakat.com sehingga semuanya akan terpantau secara terusmenerus dan meyakinkan para pembayar zakat bahwa dana zakatnya dimanfaatkan dengan benar. Pihak M-Zakat akan memberikan data baseyang ada kepada operator dan memberikan dana yang terkumpul kepada setiap amil yang tergabung di dalamnya. Sistem ini akan lebih memudahkan pembayaran zakat.

Meningkatnya jumlah dana yang dihimpun tidak hanya karena kepercayaan muzakki pada lembaga amil zakatnya. Kemudahan untuk menyalurkan dana pun menjadi faktor penyebab lainnya. Salah satu cara panting yang dilakukan untuk memberikan kemudahan dalam berzakat adalah membuka sistem pembayaran zakat melalui SMS, SMS Banking, Bank, ATM, Kartu Debit, dan onlinemelalui internet.

Adanya berbagai kemungkinan keuntungan dan kerugian yang telah dipaparkan tersebut diharapkan memberikan gambaran kepada muzakki untuk memikirkan jalan yang terbaik yang akan dipilihnya. Karena bagaimanapun setiap jalan pasti ada kendalanya. tak terkecuali dengan layanan secanggih apapun. Walaupun demikian, sudah waktunya bagi amil zakat memiliki kreativitas yang tinggi dalam melakukan dua hal. Pertama, fundrising, yaitu menghimpun dan mengumpulkan dana-dana zakat, infaq, dan shadaqah dari masyarakat.Kedua, menyalurkan secara kreatif, secara tepat sasaran, dan sesuai dengan syariah. Kreativitas ini sangat diperlukan karena kita juga harus memanfaatkan berbagai macam teknologi yang dimiliki, apakah mengumpulkan zakat melalui telepon, melalui ATM, SMS 
banking, atau dengan cara-cara yang lain. Karena potensi yang hebat ini harus digali dengan berbagai macam cara walaupun substansinya tetap. Dengan adanya Mobile Zakat orang yang akan menunaikan zakatnya akan lebih mudah dan praktis dalam pelaksanaannya.

Bagaimana dana zakat berhasil terkumpul sebanyak-banyaknya untuk kemudian disalurkan kepada umat sebanyak-banyaknya pula. Kreativitas semacam ini di kalangan amil zakat sangat diperlukan. Jika amil zakat pasif, hanya diam menanti para muzakki, didatangi para muzakki di masjid-masjid, menggunakan cara-cara lama, sudah tidak tepat lagi. Dengan berbagai kemungkinan tersebut akan menjadi keuntungan bagi muzakki untuk memilih berzakat dengan cara mana yang dikehendakinya.

Apabila dana telah dihimpun oleh lembaga zakat, adalah "menjadi tanggung jawab dari amil untuk membuat program pendayagunaan zakat agar zakat tersebut berdaya guna untuk kesejahteraan masyarakat. Masyarakat dapat mengetahui sejauh mana performance lembaga zakat melalui program pendayagunaan zakat yang diusung amil zakat. Dalam memanfaatkan dana ada beberapa hal yang harus diperhatikan agar program pemberdayaan dapat bermanfaat besar.

Salah satu aspek penting yang harus diperhatikan adalah mengenai distribusi zakat. Banyak masyarakat (muzakki) yang tak faham tentang esensi zakat yang sebenarnya, sehingga ia telah merasa melaksanakan kewajiban zakat secara sempurna, manakala ia telah mengeluarkan zakat hartanya. Padahal persoalan zakat bukan hanya sekedar mengeluarkan zakat harta, tetapi di sana ada keperluan akan manajemen distribusi zakat yang dapat secara efektif memberantas kemiskinan. Karena itulah perlu dirubah paradigma distribusi zakat agar dapat memberantas kemiskian dengan jauh lebih efektif daripada cara-cara selama ini yang banyak dilakukan oleh masyarakat. Inilah yang pernah diisyaratkan Nabi Muhammad Saw dalam sebuah hadits riwayat Bukhari, "Berzakatlah kalian, niscaya akan datang suatu masa,di mana seorang muzakki(pembayar zakat), membawa zakat hartanya, tetapi tidak menemukan lagi orang yang berhak menerimanya." Orang yang ditawari mengatakan : "Sekiranya anda datang tahun yang lalu, maka saya menerimanya". Sekarang saya tidak lagi dijumpai di Daulah Islamiyah yang sangat luas itu.

Oleh karena kemiskinan absolut telah berhasil dihapuskan, maka distribusi zakat mengalami kesulitan, sehingga terpaksa diserahkan kepada kelompok non-muslim (muallaf) di Afrika Utara. Sejarah mencatat keberhasilan zakat dalam mengentaskan kemiskinan. Zakat dikelola secara transparan dan rapi sejak masa Rasulullah Saw sampai pada masa Ummayyah, khususnyapada masa Umar bin Abdul Aziz, bahkan pada masa Khalifah Al-Manshur, negara memiliki 
surplus dana Baitul Mal sebanyak 810 juta dirham, yang disimpan sebagai devisa.

Dalam ketentuan Pasal 22 Keputusan Menteri Agama Nomor 581 Tahun 1999 tentang Pelaksanaan Undang-Undang Nomor 38 tahun 1999 tentang Pengelolaan Zakat, lembaga zakat di Indonesia harus memiliki persyaratan teknis, sebagai berikut : a) Berbadan hukum, b) Memiliki data muzakki dan mustahik, c) Memiliki program kerja yang jelas, d) Memiliki pembukuan yang baik dan e) Melampirkan surat pernyataan bersedia diaudit. Persyaratan tersebut diharapkan akan menunjang profesionalitas dan transparansi dari setiap lembaga pengelola zakat.

Dalam pengelolaan zakat, berlaku larangan sebagaimana disebutkan dalam ketentuan Pasal 37 dan Pasal 38 Undang Undang No.23 Tahun 2011 tentang Pengelolaan Zakat bahwa Setiap orang dilarang melakukan tindakan memiliki, menjaminkan, menghibahkan, menjual, dan/atau mengalihkan zakat, infak, sedekah, dan/atau dana sosial keagamaan lainnya yang ada dalam pengelolaannya. Setiap orang dilarang dengan sengaja bertindak selaku amil zakat melakukan pengumpulan, pendistribusian, atau pendayagunaan zakat tanpa izin pejabat yang berwenang.

Negara menjamin kemerdekaan tiaptiap penduduk untuk memeluk agamanya masing-masing dan untuk beribadat menurut agamanya dan kepercayaannya itu. Penunaian zakat merupakan kewajiban bagi umat Islam yang mampu sesuai dengan syariat Islam. Zakat merupakanpranata keagamaan yang bertujuan untuk meningkatkan keadilan, kesejahteraan masyarakat, dan penanggulangan kemiskinan. Dalam rangka meningkatkan daya guna dan hasil guna, zakat harus dikelola secara melembaga sesuai dengan syariat Islam, amanah, kemanfaatan, keadilan, kepastian hukum, terintegrasi, dan akuntabilitas sehingga dapat meningkatkan efektivitas dan efisiensi pelayanan dalam pengelolaan zakat.

\section{Untuk membantu BAZNAS dalam} pelaksanaan pengumpulan, pendistribusian, dan pendayagunaan zakat, masyarakat dapat membentuk Lembaga Amil Zakat (LAZ). Pembentukan LAZ wajib mendapat izin Menteri atau pejabat yang ditunjuk oleh Menteri. LAZ wajib melaporkan secara berkala kepada BAZNAS atas pelaksanaan pengumpulan, pendistribusian, dan pendayagunaan zakat yang telah diaudit syariat dan keuangan. Zakat wajib didistribusikan kepada mustahik sesuai dengan syariat Islam. Pendistribusian dilakukan berdasarkan skala prioritas dengan memperhatikan prinsip pemerataan, keadilan, dan kewilayahan. Zakat dapat didayagunakan untuk usaha produktif dalam rangka penanganan fakir miskin dan peningkatan kualitas umat apabila kebutuhan dasar mustahik telah terpenuhi.

Selain menerima zakat, BAZNAS atau LAZ juga dapat menerima infak, sedekah, dan dana sosial keagamaan lainnya. 
Pendistribusian dan pendayagunaan infak, sedekah, dan dana sosial keagamaan lainnya dilakukan sesuai dengan syariat Islam dan dilakukan sesuai dengan peruntukan yang diikrarkan oleh pemberi dan harus dilakukan pencatatan dalam pembukuan tersendiri. Untuk melaksanakan tugasnya, BAZNAS dibiayai dengan Anggaran Pendapatan dan Belanja Negara dan Hak Amil. Sedangkan BAZNAS provinsi dan BAZNAS kabupaten/kota dibiayai dengan Anggaran Pendapatan dan Belanja Daerah dan Hak Amil, serta juga dapat dibiayai dengan Anggaran Pendapatan dan Belanja Negara.

Oleh karena itu dengan adanya Mobile Zakat merupakan salah satu alternatif bagi masyarakat dalam membayar zakatnya dengan kelebihan mudah, cepat dan praktis. Harapan yang tentunya diharapkan bersama, bahwa dengan adanya Mobile Zakat tersebut dana yang terkumpul dapat dikelola dengan baik dan benar sehingga dapat sampai ke tangan yang benar-benar membutuhkan sesuai harapan pemberi zakat. Jangan sampai keberadaan MobileZakat menjadi sebuah kedok bagi penipuan bisnis sedot pulsa yang marak akhir-akhir ini. Untuk itu, provider penyedia konten sms Mobile Zakat harus benar-benar transparan dalam menyediakan layanan zakat ini. Setiap manusia tentunya hidup dalam kondisi ekonomiyang berbeda, ada yang hidupnya berkecukupan untuk dirinya, keluarga dan orang lain. Ada yang pas- pasan untuk dirinya dan keluarganya saja, ada juga yang hidupnya serba tidak berkecukupan. Rasanya sikap saling berbagi perlu terus kita bina melalui zakat, sebagai bentuk syukur kepada Allah SWT. yang telah menganugerahkan rezeki kepada kita.

Sikap peduli antar sesama juga lahir berkat kewajiban zakat ini, orang-orang kaya tergerak hatinya untuk memberi dan menyantuni fakir miskin dan kaum dhuafa, sehingga strata sosial dan dinding pemisah diantara mereka akan hilang dengan sendirinya. Ada pesan tersirat pada zakat, mengingatkan kehidupan kita yang fana ini, diri kita, harta kita, kehidupan kita, semuanya hanyalah milik Allah semata, kita tidak punya apa-apa jikalau Allah SWT tak menitipkannya kepada kita, harta dan kehidupan yang sifatnya hanyalah pinjaman, ketika Allah menagihnya tak ada alasan bagi kita untuk tidak mengembalikannya. Secara bilangan dan kasat mata, mungkin ketika berzakat harta kita akan berkurang, tapi yakinlah sebenarnya kita telah melakukan investasi yang besar, investasi yang kekal selama-lamanya di sisi Allah, dengan keuntungan berlipat ganda dan tidak pernah ada istilah rugi.

\section{PENUTUP}

Pertanggungjawaban dan akuntabilitas pengelolaan dan pendistibusian MZakat dapat dipantau melalui telepon seluler dengan fasilitas SMS, dan internet, dengan alamat www.m-zakat.comsehingga semuanya akan terpantau secara terus-menerus dan 
meyakinkan para pembayar zakat bahwa dana zakatnya dimanfaatkan dengan benar. Pihak M-Zakat akan memberikan data baseyang ada kepada operator dan memberikan dana yang terkumpul kepada setiap amil yang tergabung di dalamnya.

Hendaknya

BAZNAS

menyelenggarakan zakat sms yang serupa dengan konsep M-Zakat namun tidak mempunyai motif bisnis dan lebih bersifat nirlaba dan murni sosial. Harapan yang tentunya diharapkan bersama, bahwa dengan adanya Mobile Zakat tersebut dana yang terkumpul dapat dikelola dengan baik dan benar sehingga dapat sampai ke tangan yang benar-benar membutuhkan sesuai harapan pemberi zakat. Jangan sampai keberadaan Mobile Zakat menjadi sebuah kedok bagi penipuan bisnis sedot pulsa yang marak akhir-akhir ini. Untuk itu, provider penyediakonten sms MobileZakat harus benar-benar transparan dalam menyediakan layanan zakat ini.

\section{DAFTAR PUSTAKA}

Didin Hafidudhin,. 2002. Zakat dalam Perekonomian Modern. Gema Insani. Jakarta

Kafrani Ridwan. 1993. Zakat. ikhtiar Baru Van Hoeve. Jakarta.

Mohammad Daud Ali. 1988. Sistem Ekonomi Zakat dan Wakaf. UIPress. Jakarta.

Abdurrahman Qadir. 1998. Zakat Dalam Dimensi Mahdah dan Sosial. Raja Grafindo Persada. Jakarta.
Sulaiman Rasjid. 1976. Fiqih Islam. Attahiriyah. Jakarta

Sayyid Sabiq, 1968. Fiqh al-Sunnah. Daar el-Bayan, Kuwait

Yusuf Qardhawi, 1995. Kiat Islam Mengentaskan Kemiskinan. Gema Insani Press. Jakarta.

Undang-Undang Republik Indonesia Nomor 36 Tahun 1999 tentang Telekomunikasi.

Undang-Undang Republik Indonesia Nomor 38 Tahun 1999 tentang Pengelolaan Zakat.

Keputusan Presiden Republik Indonesia Nomor 8 Tahun 2001 tentang Badan Amil Zakat.

Keputusan Menteri Agama Republik Indonesia Nomor 581 Tahun 1999 tentang Pelaksanaan UndangUndang Nomor 38 tahun 1999 tentang Pengelolaan Zakat. Sebagaimana telah disempurnakan dengan Keputusan Menteri Agama Nomor 373 tahun 2003.

Pengelolaan keputusan Dirjen Bimas Islam dan Urusan Haji Nomor D/291 tentang Pedoman Teknis akat. 